\title{
CUSTOMERS, CONTROL, AND THE PERFORMANCE OF ISLAMIC BANKS
}

\author{
AHMADASRI ALAUDIN 1
}

Received: 19 September 2019 / Revised: 4 March 2020/ Accepted: 12 March 2020

(C) 2021 Faculty of Business and Accountancy, Universiti Malaya. All rights reserved.

\section{A B S T R A C T}

Research aim: This study explores the relationship between customer fairness and trust building and the performance of bank branches.

Design/Methodology/Approach: Methodologically, this relationship is first explored with no mediating variable using bivariate correlation analysis as a precursor to a more sophisticated path analysis where this relationship is hypothesized to be mediated by control systems. The data for these analyses are subjective assessments elicited from a survey of branch managers working in two different Islamic banks in Malaysia.

Research Findings: Overall, the results suggest that customer trust building is an important determinant of performance relative to expectations, both directly and indirectly through the use of control systems. However, there is less support for a significant association between customer fairness building and performance.

Theoretical contribution/Originality: Given the impressive growth in the size and popularity of Islamic banking around the world, it is an increasingly pertinent domain for academic research. This study has sought to contribute to this literature from the perspective of organizational dynamics and organizational performance as perceived by branch managers. It also contributes to Simons' levers of control framework by operationalizing its belief system lever using values (i.e., trust and fairness building).

Practitioner/Policy implication: Bank management both at corporate and business (operating) levels may benefit from the findings in implementing strategy and developing value-based competitive advantage in a form of trust and fairness.

Limitation/Implication: The lack of support for customer building results may provide opportunity for further research into this. It would have been interesting to elicit views from a wider range of bank personnel (i.e., regular employees as well as branch managers). Whilst on the other hand it may have been beneficial to utilize more objective measurements, particularly with respect to performance.

Keywords: Control systems, Fairness, Islamic banks, Malaysia, Path analysis, Trust Type of article: Research paper

JEL Classification: G21, M41, M31

\section{Introduction}

The growth of Islamic banking throughout the world has been tremendous (Cham, 2018; Olson \& Zoubi, 2008) and therefore worthy of research. Focusing on Malaysia, Ariff (2017) notes how assets of Islamic banks stood at USD\$535 billion in 2015, compared to only USD\$83 billion in 2007. The increasing number of Islamic banks and bank branches in Malaysia has contributed to

\footnotetext{
${ }^{1}$ Accounting Tunku Intan Safinaz School of Accountancy, Universiti Utara Malaysia, Sintok, Kedah, Malaysia. *Corresponding author, e-mail: ahmadasri@uum.edu.my; aalaudin17@gmail.com
} 
rising competition. Hence, Islamic banks, particularly those which were established early, must be concerned with how to create and sustain competitive advantages. This study explores the orientation towards customers as reflected through fairness and trust building and the implications this has on banks' performance, both directly and indirectly through interactive and diagnostic control systems. Focusing on how (and the extent to which) banks and their branches prioritize building and maintaining fairness and trust vis-àvis their customers is important because these represent fundamental principles in Islamic banking.

According to Abu-Tapanjeh (2009), a major ethical component of any economic activity in Islam is to provide justice, honesty, and fairness and to ensure all parties their rights and dues. Customers should not be exploited through any practices (Hassan et al., 2008). Any act of injustice can negate the concept of brotherhood among fellow believers (Saeed et al., 2001). Moreover, economic goals should not be the only focus since Islamic banks are also expected to contribute to social development. The economic benefits received by customers, among others, are shariah-compliant financial services in return for repayment of the financing.

There are some inadequacies of past studies in Islamic banking in Malaysia. First, most studies into Islamic banking focus only on technical aspects of product offerings - shariah-compliant or not (e.g., Rosly \& Sanusi, 1999), or "efficiency" concept (Farell, 1957; Liebenstein, 1966) for banking performance (e.g., Kamarudin et al., 2008). However, little has been researched on the role of management practices, in particular, management control mechanisms on bank performance. Most research which examines customer relations using equity theory gives focus on pricing - whether price is fair or unfair.

Second, control systems are mostly studied from the perspective of top management, in particular how it allows them to monitor whether and the extent to which given objectives have been achieved. However, little is known about the types of control mechanisms and how they are used at the operating level in implementing business strategy. This study investigated control systems at the branch-level of operations, closely connected to the specifics of particular operational practices. Focusing on branch managers, rather than executives at head offices, is thus important, particularly where heterogeneities exist across branches relative to higher level strategies and opinions (Chaganti \& Sambharya, 1987; Georgakakis et al., 2017; Golden, 1992; Parnell, 1997).

In sum, this study examines the relationships between customer fairness building, customer trust building, control systems, and organizational performance based on survey data garnered from a sample of branch managers at two different Islamic banks in Malaysia. The remainder of the paper is structured as follows. Section 2 delineates the conceptual framework and the study's hypotheses before the relevant methodologies are elaborated in Section 
3. Empirical results are presented and discussed in Section 4. Finally, conclusions are offered in Section 5 including details of the study's limitations and how these could provide a fruitful basis for future research in this domain.

\section{Literature Review and Hypotheses Development}

In the current study both fairness and trust are viewed as one which has strategic importance (Barney \& Hansen, 1994). Therefore, it is of significance that managers have some degree of influence on fairness and trust building. The notion of organizational justice and Mayer et al.'s (1995) model for trust are used in order to examine the extent of fairness and trust being practised by managers of Islamic banks. Simons' control levers are drawn to understand how managers control organizational purpose and basic values i.e., fairness and trust and their roles in influencing performance.

\subsection{Customer fairness and trust building (beliefs systems) and performance}

There is a substantial body of literature concerned with fairness in organizations. The term "organizational justice" was originally coined by Greenberg in the 1980's (Cropanzano \& Greenberg, 1997) and has generally been postulated to encompass three different components (Bowen et al., 1999; Folger \& Cropanzano, 1998). Distributive justice is largely based on equity theory (Adams, 1965) and refers to the perceived fairness of outcomes that an individual receives (Cropanzano \& Folger, 1991). Procedural justice is the perceived fairness of procedures which are used to determine outcome decisions (Folger \& Konovsky, 1989). Interactional justice was conceived by Bies and Moag (1986) and relates to the perceived fairness of the interpersonal communication relating to organizational procedures."

Fairness involves aspects of the communication process such as politeness, honesty, and respect (Bies \& Moag, 1986; Tyler \& Bies, 1990). The justice literature has a strong theoretical base in terms of conceptions and perceptions of fairness and has been used to explain reactions to various types of employee actions (e.g., Gilliland, 1993). Perceptions of fairness can logically be related to positive organizational outcomes and the corollary of this must be that perceptions of unfairness may result in negative consequences for organizations, such as workplace sabotage (Ambrose \& Cropanzano, 2003; Hollensbe et al., 2008; Masterson, 2001; Schminke et al., 2015). As far as the interactional dimension of fairness is concerned, justice research indicates that the quality of interpersonal treatment that individuals receive impacts their perceptions of fairness (Bies \& Moag, 1986; Lind \& Tyler, 1988; Tyler \& Bies, 1990; Tyler \& Lind, 1992).

Mayer et al. (1995) developed a useful model of trust where they differentiate trust from factors that contribute to trust. This framework 
considers factors contributing to trust in the form of beliefs about another party's ability, benevolence, and integrity. These elements of trustworthiness (as precursor of trust) are the predominant determinants of trust. Thus, branch managers can develop customer trust by shaping the ability, benevolence, and integrity of their branch resources (including employees). In marketing literature, it has been shown that trust factor may influence the degree of satisfaction in the relationship between producers and consumers via distribution channels (Anderson \& Narus, 1990). And with the growing importance of relationship marketing, some authors even argue that this notion is built upon a foundation of trust foundation (Berry, 2000). It is the key element in long-term relationship between business and customers. Marketing theories provide the basis for predicting the role of customer trust building in organizational performance. It is the fulfilment of customers' expectations that enhances organizational performance. Branch may portray its benevolence by showing respect (e.g., salam greeting) and understanding of customers' needs. Customer trust is an essential precursor to the establishment of strong transactional relationships and sustainable market share (Urban, Sultan, \& Qualls 2000).

The importance of employees' interactions in influencing customer satisfaction and loyalty is well documented in the banking services literature (Jamal \& Kamal, 2003; Metawa \& Al-Mossawi, 1998; Naser et al., 1999). Indeed, personal interactions between branch employees and customers often becomes a focal point in evaluations of the entire service organization (Bitner et al., 1990; Mattsson, 1994; Zeithaml et al., 1988). Trust is described as one of the dimensions for determining the quality of the relationship between customers and sales personnel (Crosby et al., 1990) and it is more important in relational contexts where customers seek predictable and obligatory behavior from the other party. Thus, the element of trust is particularly crucial in Islamic banking where Muslim customers, in particular, have to rely on banks to fulfil their shariah-compliant financing needs. From the perspective of devout Muslim customers, the responsibility of seeking God's redha or consent is obligatory upon every Muslim. This includes obtaining halal financing or loans which are supposed to be free from riba. It follows that customers must rely on and trust Islamic banks to provide the requisite solutions. As argued by Gambling et al. (1993), devout Muslims "expect the [Shariah Committee] to be able to [ensure] this" (p.202). Luhmann (1979) views this as a trust in systems and, taken this way, Islamic banks are systems regulated by Bank Negara Malaysia (BNM), which is the Central Bank of Malaysia. Customers who deal with Islamic banks have some degree of expectation that the financial transactions are in conformity with Islamic law, the shariah. This is a form of trust that they have towards Islamic bank. Trust in this sense entails responsibility (Flores \& 
Solomon, 1998) on the part of Islamic bank. The foregoing leads to the following hypothesis:

H1a: The extent to which a bank branch builds customer fairness is positively associated with branch performance.

H1b: The extent to which a bank branch builds customer trust is positively associated with branch performance.

\subsection{Control systems}

It is common industry practice for banks to organise their branches as profit centres to exercise control (Anthony \& Govindarajan, 2007). Branch managers are responsible for targeted profit and thus would focus their attention on revenue generating and cost containment activities. Thus, the head office management only focuses on the "results" and allows branch managers to use their effort and creativity in managing resources/"inputs" (including employees) and the "process" (e.g., servicing customers, processing loan applications) to achieve the results. Information generated by control systems is used to monitor the accomplishment of specified objectives, to direct attention, to allow learning, and to coordinate and support decision making (Abernethy \& Vagnoni, 2004; Simons, 1995). The accomplishment of specified objectives, which reflects diagnostic control, is used by managers to monitor staff performance. For example, through reward systems, conditions are created to motivate employees to achieve predetermined or desirable outcomes. However, many authors argue that the monitoring function of control systems implies the assumption of opportunistic behaviors by employees and can cause suspicion in the manager-employee relationship (Sitkin, 1995). According to Velez et al. (2008) those who hold this view tend to treat monitoring as an alternative to trust.

Past studies have examined the possible mediating role of control systems in strategy and performance relationships e.g., Hoque (2004). Drawing on Simons (1995) control levers, this study argues that managers might use control systems along an interactive-diagnostic continuum. At one end, managers who focus more on monitoring would also likely give more attention to achieving pre-determined outcomes and pay less attention to customers as strategic resources that need bespoke and appropriate treatment i.e., by building relationships with them. At the other end of the spectrum, managers who use control systems in more of an interactive, coordinating sense will tend to view their role as being a facilitator and enabler (Ahrens \& Chapman, 2004) with objectives in terms of sharing information, directing attention, assisting, and allowing learning. Customer fairness and trust building potentially allows for more openness that facilitates communication. Hence, these objectives can 
support the interactive use of control systems, encouraging managers to engage in frequent information exchanges with employees.

This study considers how the intensity of use of control systems (diagnostic/interactive) affects the relationship between customer fairness and trust building and performance as a mediating variable. The following hypothesis is thus posited:

H2a: $\quad$ There is a positive indirect relationship between customer fairness building and branch performance acting through the intensity of use of control systems.

H2b: $\quad$ There is a positive indirect relationship between customer trust building and branch performance acting through the intensity of use of control systems.

\section{Methods}

\subsection{Sampling frame}

The sampling frame is constituted by branch managers (micro-frame) in two Islamic banks (meso-frame) in Malaysia (macro-frame). These two banks were among the first Islamic banks to be established in Malaysia and henceforth, to preserve confidentiality, they are referred to by pseudonyms, Malpha Bank and Reta Bank.

\subsubsection{Malpha Bank}

Malpha Bank is a fully-fledged Islamic financial institution under the Islamic Banking Act (1983). Nevertheless, it is relatively small based on its assets and network of branches. At the time of data collection, it had 48 branches in Malaysia with between 4 and 24 employees per branch (the norm was around 15 employees). Malpha Bank centralizes most of its operations to Head Office. For example, all financing approvals occur through the Retail Processing Centre, one of the units under the Credit Management Division, at Head Office. At the branch level, activities are more geared toward identifying customers, getting correct documentation, and giving recommendations. However, branches are also responsible for identifying, measuring, and mitigating credit risk in the overall credit appraisal process. Bank branches are focused on retail and consumer products and services. Accordingly, institutional banking falls outside of the sampling frame because this is within the remit of the wholesale banking unit at Head Office, rather than the branches.

In managing a business unit, a branch manager in general views his/her branch as comprising two sections. That is, one which involves normal operations of counter/teller services. The day-to-day activities are characterized by routines, standardized operating procedures, and formal rules. The objective is to achieve efficiency in delivering services and thus can 
be termed as mechanistic in nature. In this regard, the distribution of responsibility and authority to assistant branch managers provided by the bank's structure is clearly identified. The second section is income generating activities which involve sales of financial products including property financing, hire purchase for individual and commercial customers, and structured personal financing. This is the area where branch managers focus more intensely, and it requires building relationships with customers (individuals and businesses) and intermediaries (property developers and legal firms).

\subsubsection{Reta Bank}

Although Reta Bank commenced operations many years ago, it is in the last 20 years that is has grown significantly. In 1993, it took an important step towards becoming a shariah compliant bank by introducing Islamic banking products at four of its branches. Then, in 2002, it became a fully-fledged Islamic bank. Since then, it has invested significantly in branch development. As of 2007, Reta Bank had a total of 121 branches throughout Malaysia, with around 21 employees per branch. Thus, it is significantly larger than Malpha in terms of operational capacities. Indeed, Reta has specifically moved towards building its image as a vibrant and modern bank so that it is comparable to, and competitive with, established conventional banks.

Reta's core product is personal financing targeted at government employees (civil servants). For this type of loan, repayments are normally arranged through salary deduction by the borrower's employer hence the default risk is relatively low. In the face of fierce competition from conventional as well as new and existing Islamic banks in the country, Reta had taken a more aggressive approach in its marketing and promotional activities. Targets are set by Head Office and disseminated to regions and branches at annual meetings which all branch managers attend. Branch managers have relative autonomy in terms of processing financing applications and compared to Malpha, Reta was observed to focus more on instituting working teams (e.g., each branch has a sales team) for the purpose of meeting daily and longer-term objectives. This contrasts with Malpha which relied more on hierarchical structures whereby branch managers and assistant managers were the key decision makers.

\subsection{Survey design}

\subsubsection{Building customer fairness and trust}

The two constructs related to customers were developed to measure the extent of managers' efforts and initiatives to build trust and fairness with customers. Each branch manager was directed to respond to a total of 19 statements, each answerable using the same 7-point Likert-type format ranging from (1) strongly 
disagree to (7) strongly agree (see the Appendix). Measures of fairness building in relation to customers were adapted from Kumar, Lisa, \& Steenkamp (1995). The items required each branch manager to assess the fairness of his or her employees in relation to customer services. Fairness implies accuracy in information gathering, feedback and explanation of results, consistent application of standards, and clear understanding by the persons served (Greenberg, 1986). In other words, fairness perceptions are determined by both outcomes and the processes followed to arrive at the outcomes.

The perceived building of customer trust was measured with items adapted from Crosby et al. (1990). In their study of consumer-based relationship quality, Crosby et al. (1990) examine trust in the salesperson and satisfaction with the salesperson as two important dimensions of the quality of the relationship. Herein, only the trust dimension from that study was used. Although some adaptations were made to the original items to suit the banking industry in Malaysia, it is generally fit-for-purpose because it is comprehensive, empirically grounded, and was subsequently validated by Boles et al. (2000).

Table 1 Operationalizing branch managers' subjective perceptions of control systems

\begin{tabular}{|c|c|c|c|c|}
\hline Control Systems & & $\begin{array}{l}\text { Ittner \& } \\
\text { Larcker } \\
(1997)\end{array}$ & $\begin{array}{l}\text { Current } \\
\text { Study }\end{array}$ & Comment \\
\hline \multirow[t]{3}{*}{ Implementation } & $\begin{array}{l}\text { Action plans } \\
\text { or targets }\end{array}$ & 4 items & 4 items & No comment \\
\hline & $\begin{array}{l}\text { Project } \\
\text { selection }\end{array}$ & 2 items & Omitted & Not relevant \\
\hline & $\begin{array}{l}\text { Measures and } \\
\text { Rewards }\end{array}$ & 3 items & 8 items & Customer items added \\
\hline \multirow[t]{3}{*}{$\begin{array}{l}\text { Internal } \\
\text { Monitoring }\end{array}$} & $\begin{array}{l}\text { Quality } \\
\text { feedback }\end{array}$ & 3 items & 11 items & $\begin{array}{l}\text { Quality feedback and } \\
\text { management reviews }\end{array}$ \\
\hline & $\begin{array}{l}\text { Management } \\
\text { reviews }\end{array}$ & 3 items & & $\begin{array}{l}\text { combined under 'Feedback } \\
\text { systems'; customer items } \\
\text { added }\end{array}$ \\
\hline & $\begin{array}{l}\text { Board } \\
\text { reviews }\end{array}$ & 6 items & Omitted & Not relevant \\
\hline \multirow[t]{5}{*}{$\begin{array}{l}\text { External } \\
\text { Monitoring }\end{array}$} & Importance & Omitted & 2 items & $\begin{array}{l}\text { Added to measure } \\
\text { importance with regard to } \\
\text { customers }\end{array}$ \\
\hline & $\begin{array}{l}\text { Market } \\
\text { research }\end{array}$ & 3 items & 3 items & No comment \\
\hline & Benchmarkin & 7 items & 3 items & \multirow{3}{*}{$\begin{array}{l}\text { Reduced to suit banking } \\
\text { context } \\
\text { No comment }\end{array}$} \\
\hline & $\begin{array}{l}\mathrm{g} \\
\text { Strategic } \\
\text { audits }\end{array}$ & 3 items & 3 items & \\
\hline & Total & 36 items & 34 items & \\
\hline
\end{tabular}




\subsubsection{Control systems}

To measure control systems, the study adapted Ittner and Larcker's (1997) strategic control construct which comprises questions grouped into three sections: implementation, internal monitoring, and external monitoring. Each section is then further broken down into sub-sections. Through modification and adaption, the 36 questions in the original questionnaire were reduced to 34 (see Table 1 for a summary and the Appendix for full details). All questions related to control were answerable using the same 5-point Likert format $(1=$ "unimportant" through to 5 = "very important") which contrasts with Ittner and Larcker (1997) who used a 4-point scale $(1=$ "Slight or Not at all" through to $5=$ "Primary"). There is a burgeoning literature exploring the optimal number of alternatives for Likert scale items and whilst there are non-trivial differences of opinion, the evidence on aggregate tends to favor between 5-7 response-options (e.g., Cox III, 1980; Croasmun \& Ostrom, 2011; Preston \& Coleman, 2000).

\subsubsection{Internal Monitoring}

The Internal monitoring section was constructed to gather information on how management at different levels use their control systems i.e., interactively or diagnostically (Simons, 1995). This section began by asking five importance questions, followed by six frequency questions. The focus here was on efforts, results, measurements, and reporting related to winning and retaining customers. Whilst the salience of efforts and results is intuitive, it's also important to remember that measurement and reporting are critical as well. Indeed, strategic control systems' advocates argue that the provision of frequent feedback on actual results against strategic targets and objectives allows timely corrective action to be taken (e.g., Goold \& Quinn, 1993; Govindarajan \& Shank, 1995; Ittner \& Larcker, 1997). The Board reviews subsection in Ittner \& Larcker (1997) was dropped because our sampling frame is limited to branch managers and it was thus deemed unlikely that they could give valid information on directors' activities.

\subsubsection{External monitoring}

Finally, the external monitoring dimension of the control systems construct asked branch managers to respond to 11 different questions, all answerable on 5-point Likert scales. This opened with two Importance questions: 'In your bank's strategic planning process, how important is external information with regard to (a) building relationships with customers? (b) building relationships with employees? Next, three Market research questions focused on the frequency with which information from market research studies is used by branch managers in different contexts. The remaining questions followed a 
similar format, seeking to ascertain the frequency with which Benchmarking (3 questions) and Strategic reviews (3 questions) were used in different contexts. In terms of the former, the opening question asked: 'How often is benchmarking used to monitor your operations with respect to banking products and services? Whilst in terms of the latter the opening question was as follows: 'How often is process technology reviewed to monitor the position of your banking operations?

\subsubsection{Performance}

Following past studies (Bisbe \& Otley, 2004; Chenhall \& Langfield-Smith, 1998; Gupta \& Govindarajan, 1984), performance was operationalized as the degree of goal attainment along financial and non-financial measures. Specifically, performance was measured in terms of financial, human resource, and customer dimensions (see Table 2 for a summary and the Appendix for full details). First, branch managers were required to rate the importance of each financial measure (four items), human resource measure (six items), and customer measure (four items). In each case, a five-point Likert type scale was used $(1=$ "very slightly important" through to $5=$ "very significantly important"). Next, using the same 14 items, respondents were then asked to rate how their respective branch performs (i) as compared to their competitors and (ii) as compared to their expectations. For this latter exercise, the five-point scale ranged from 1 ("significantly worse than") through to 5 ("significantly better than").

Table 2 Operationalizing branch managers' subjective perceptions of performance

\begin{tabular}{lll}
\hline \multicolumn{1}{c}{ Financial } & \multicolumn{1}{c}{ Performance } \\
\hline Outstanding financing & Employee retention & \multicolumn{1}{c}{ Customers } \\
Outstanding deposits & Employee satisfaction & Customer share \\
Branch profit & Employee participation & Customer complaints \\
Non-performing & Cross-training of employees & Customer satisfaction \\
financing (NPF) level & Commitment to customers & \\
& Employee suggestions & \\
\hline
\end{tabular}

\subsection{Survey pretest}

As a pre-test, a survey and cover letter were sent to 25 randomly selected branches of a third Islamic bank in Malaysia. Based on the returned surveys (20 respondents; $80 \%$ response rate), the reliability of the survey constructs (scales) was determined using the Alpha model to quantify the extent to which internal consistency was upheld. The number of items that composed the scale for each construct and the respective alphas are reported in Table 3. 
Next, to confirm the dimensions for each of the constructs, factor analyses were carried out. More specifically, dimensions or factors associated with each construct were extracted by means of the Principal Axis Factoring method. Factor loadings from the extraction procedures were rotated to identify items which underlie each construct; loadings below 0.50 were considered unimportant (Kim \& Mueller, 1978), thus this was used as a cut-off point for determining the salient items of corresponding dimensions for all constructs.

Table 3 Cronbach's alpha for the fairness, trust, control, and performance constructs

\begin{tabular}{lcc}
\hline Construct & Alpha (Cronbach) & N of items \\
\hline Customer fairness building & 0.925 & 10 \\
Customer trust building & 0.950 & 9 \\
Control systems & 0.868 & 34 \\
Importance of performance measures & 0.952 & 14 \\
Performance against competitors & 0.931 & 15 \\
Performance against expectations & 0.939 & 15 \\
\hline
\end{tabular}

\subsection{Survey distribution and response rate}

The two participating banks, Malpha and Reta, had a combined total of 156 branches between them at the data collection stage. In 2008, all branch managers were sent a survey package which included a cover letter that explained the purpose of the research, a questionnaire, and a postage-paid return envelope. Two weeks after the initial mailing, reminders were issued through phone calls and, in some cases, emails to branch managers who did not respond to the initial survey. The end result was a total of 91 usable questionnaires (response rate $=58 \%$ ).

\subsection{Inferential methods (hypothesis testing)}

To test H1, simple bivariate parametric correlation coefficients are calculated between customer fairness and trust building on the one hand and performance compared to expectations and competitors on the other hand. To test $\mathrm{H} 2$, a path model was constructed as depicted in Figure 1. Path models can be regarded as a natural extension of multiple regression analysis, which has a long history in the theoretical and applied literature. Where they differ, and thus the rationale for path analysis, is in term of mediating variables. In the conceptual and operational framework of this study, this means that both fairness and trust building are treated as exogenous variables. By contrast, both control and performance are endogenous variables because of their dependence on fairness building, trust building, and residuals e 3 and e4 which are variables outside the path model.

The relationship between fairness building and performance as represented by r14 can be decomposed into a direct effect and indirect effect (Equation 1) 
with the same logic being applied to understand the correlation between trust building and performance.

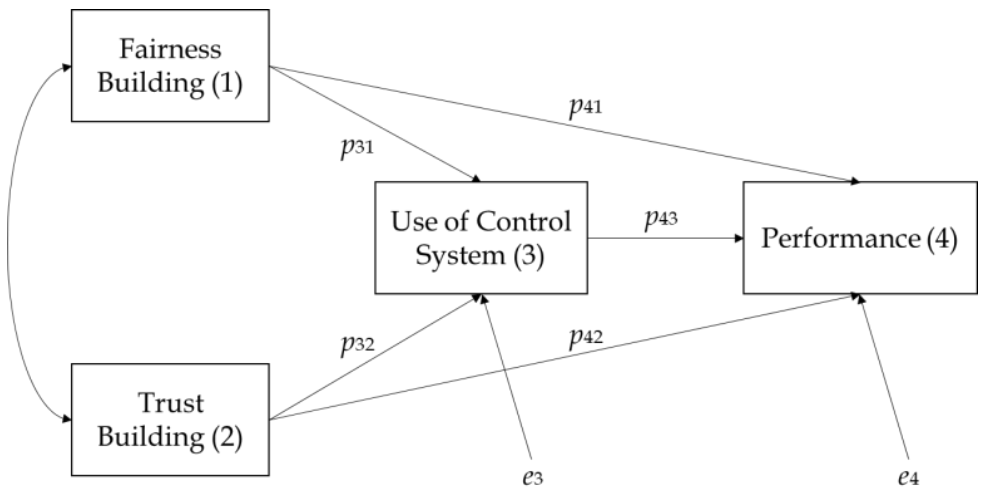

Figure 1 Customer fairness and trust building, use of control systems, and organizational performance: A path model

$$
r_{14}=\underbrace{p_{41}}_{\begin{array}{r}
\text { Direct } \\
\text { Effect }
\end{array}}+\underbrace{p_{43} p_{31}}_{\begin{array}{c}
\text { Indirect } \\
\text { Effect }
\end{array}}+\underbrace{p_{42}}_{\text {Unanalyzed }} p_{21}+p_{43} p_{32} p_{21}
$$

Moving on, there are two indirect effects identified in Figure 1, namely (1) $\rightarrow(3) \rightarrow(4)$ and (2) $\rightarrow$ (3) $\rightarrow$ (4) In words, fairness building, and trust building can indirectly influence performance via the use of control systems.

\section{Results and Discussion}

\subsection{Descriptive statistics}

Table 4 lists the subjectively ascribed importance of financial, customer, and employee performance measures ranked by descending mean scores.

The top three measures in terms of subjectively ascribed importance by the branch managers in the sample are all financial metrics i.e., branch profit, NPF level, and outstanding financing. Customer satisfaction and customer complaints rank fourth and fifth, respectively. The highest ranked employee related metric is actually oriented towards customers (i.e., commitment to customers). Interestingly, the variability in ascribed importance is higher for lower rank measures of performance. This can perhaps be explained by the nature of non-financial measures which are more subjective than financial measures and thus amenable to relatively heterogenous interpretations and 
understandings between branch managers. In sum, the results suggest that branch managers regard financial measures as the most important constituents of performance followed by customer-oriented metrics and, finally, employeeoriented metrics.

Table 4 Descriptive statistics for performance measures

\begin{tabular}{lccccc}
\hline Performance Measures & $\begin{array}{c}\text { Theoretical } \\
\text { range }\end{array}$ & Min & Max & Mean & $\begin{array}{c}\text { Std. } \\
\text { Dev. }\end{array}$ \\
\hline Branch profit & $1-5$ & 3 & 5 & 4.846 & 0.392 \\
NPF level & $1-5$ & 2 & 5 & 4.791 & 0.506 \\
Outstanding financing & $1-5$ & 1 & 5 & 4.758 & 0.565 \\
Customer satisfaction & $1-5$ & 1 & 5 & 4.643 & 0.688 \\
Customer complaints & $1-5$ & 2 & 5 & 4.5 & 0.687 \\
Outstanding deposit & $1-5$ & 1 & 5 & 4.445 & 0.747 \\
Customer retention & $1-5$ & 1 & 5 & 4.363 & 0.888 \\
Commitment to customers & $1-5$ & 1 & 5 & 4.269 & 0.8 \\
Market share & $1-5$ & 2 & 5 & 4.214 & 0.824 \\
Employee satisfaction & $1-5$ & 1 & 5 & 3.973 & 0.938 \\
Employee participation & $1-5$ & 1 & 5 & 3.962 & 0.932 \\
Employee retention & $1-5$ & 1 & 5 & 3.824 & 0.838 \\
Employee suggestion & $1-5$ & 1 & 5 & 3.78 & 0.94 \\
Cross-training of employees & $1-5$ & 1 & 5 & 3.742 & 0.804 \\
\hline
\end{tabular}

\subsection{Inferential results: Bivariate parametric correlations (Hypothesis 1)}

To test H1, customer fairness building, and customer trust building were examined against overall performance compared to expectation and overall performance compared to competitors (Table 5).

Table 5 Bivariate parametric correlations

\begin{tabular}{lcc}
\hline & Customer fairness & Customer trust \\
\hline Overall performance & $r=0.262$ & $r=0.198$ \\
compared to expectation (3) & $\mathrm{P}=0.013$ & $\mathrm{P}=0.062$ \\
Overall performance & $r=0.136$ & $r=0.165$ \\
compared to competitors (4) & $\mathrm{P}=0.200$ & $\mathrm{P}=0.119$ \\
\hline
\end{tabular}

Both customer fairness building and customer trust building exhibit significant positive associations with overall performance compared to expectations $(\mathrm{p}<0.05$ and $\mathrm{p}<0.10$, respectively). Put differently, in the opinion of branch managers, the extent to which they and their teams work towards building customer trust and fairness is positively associated with the extent to which themselves and their teams are performing well relative to their expectations. However, neither customer fairness building nor customer trust building exhibit significant associations with overall performance compared to competitors. Hence, these results partially support H1a and H1b. Arguably, 
this inconsistency is ostensible, for two possible reasons. First, the lack of association between trust and fairness on the one hand and performance relative to competitors on the other hand could be due to the fact that respondents have limited access to information regarding their competitors' performance. Secondly, it could also reflect an ethical/conceptual disjoint i.e., building fairness and trust is important for non-monetary as well as monetary reasons whereas performance compared to competitors specifically implies a neoclassical, monetary framing.

\subsection{Inferential results: Path analysis (Hypothesis 2)}

Here the results of a path analysis allow quantification and exploration of the extent to which there are causal relationships among customer trust building, customer fairness building, the intensity of control use, and overall performance compared to expectations (Table 6 and Table 7). Based on the results from testing $\mathrm{H} 1$ in sub-section 4.2 which only showed significant associations between fairness and trust metrics versus performance compared to expectations, and because that hypothesis was a precursor to H2 both conceptually and analytically, overall performance compared to competitors is not considered here.

Table 6 Customer fairness and trust building and the use of control systems: The first part of the path model

\begin{tabular}{lcccccc}
\hline Linkage & $\begin{array}{c}\text { Total } \\
\text { Effect } \\
\left(\mathrm{r}_{\mathrm{ij}}\right)\end{array}$ & $\begin{array}{c}\text { Direct } \\
\text { Effect } \\
\left(\mathrm{p}_{\mathrm{ji}}\right)\end{array}$ & $\begin{array}{c}\text { Indirect } \\
\text { Effect }\end{array}$ & $\begin{array}{c}\text { Spurious } \\
\text { Effect }\end{array}$ & Unanalysed \\
\hline $\begin{array}{l}\text { Customer fairness } \\
\text { building / Use of } \\
\left.\text { control systems ( } \mathrm{r}_{13}\right)\end{array}$ & 0.231 & 0.087 & & & 0.144 \\
$\begin{array}{l}\text { Customer trust } \\
\text { building / Use of } \\
\text { control systems }\left(\mathrm{r}_{23}\right)\end{array}$ & 0.268 & 0.208 & & & 0.060 \\
\hline
\end{tabular}

Neither of the path coefficients in Table 6 are statistically significant. In other words, customer trust building, and fairness building do not have significant direct effects on the intensity of use of control systems.

In terms of Table 7 , there is a significant positive relationship between customer fairness building and performance $\left(r_{i j}=0.262, p<0.05\right)$. However, the path coefficient is not significant $\mathrm{p}_{\mathrm{ij}}=0.208, \mathrm{p}>0.1$. Thus, there is no significant direct effect of customer fairness building on overall performance compared to expectations. Moreover, the indirect effect of customer fairness building on expected performance via the use of control system systems is very low (0.026), accounting for just under $10 \%$ of the correlation coefficient $r_{24}$. Hence, the results do not support $\mathrm{H} 2 \mathrm{a}$ : there is no positive significant indirect relationship 
between customer fairness building and overall expected performance acting through the use of control systems.

Table 7 Customer fairness and trust building, the use of control systems, and organizational performance: The second part of the path model

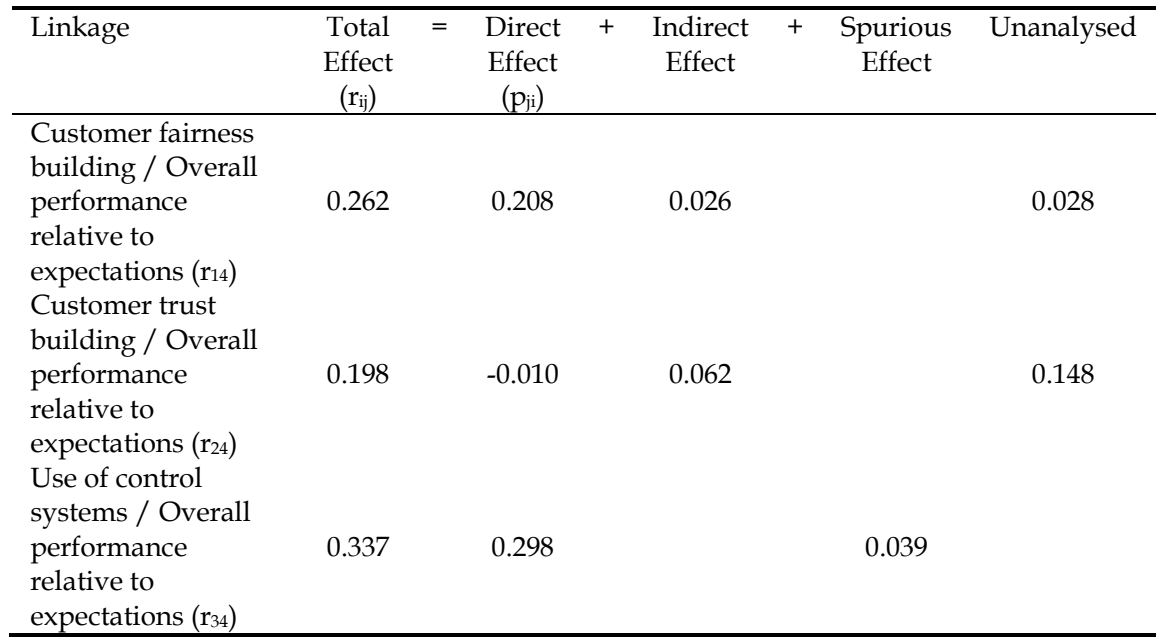

Moving on, the results suggest that the extent to which branch managers build customer trust is positively associated with overall performance compared to expectations $\left(\mathrm{r}_{\mathrm{ij}}=0.198, \mathrm{p}<0.10\right)$. Further, the indirect effect of customer trust building on overall performance compared to expectations acting through the use of control systems is relatively high (the effect coefficient $>30 \%$ ). Thus, these results support $\mathrm{H} 2 \mathrm{~b}$ : there is a positive indirect relationship between customer trust building and branch performance acting through the use of control systems. It is interesting to note that this indirect effect is greater than the related direct effect.

\section{Conclusions}

This study has explored relationships between customer fairness and trust building and the performance of a total of 91 branches belonging to two different Islamic banks in Malaysia. First, these relationships were explored with no mediating variable as a precursor to a more sophisticated analysis where these relationships were hypothesized to be mediated by the use of control systems. In terms of the initial, precursor analysis, bivariate correlation analysis suggested that both customer fairness building and customer trust building exhibit significant positive associations with performance relative to expectations. This finding is consistent with previous studies on Islamic 
banking; for example, Dayan et al. (2008) show that interactional justice increases the loyalty of banking customers. Interestingly, where performance is conceived and configured relative to competitors, no significant associations were revealed with these fairness and trust metrics. This could plausibly be explained in terms of either or both of two factors. First, branch managers may only have partial or outdated knowledge and information about the performance of their competitors, thus compromising the reliability and validity of their responses in this respect. Second, a priori, it could be argued that trust and fairness building are not logically related to performance compared to competitors because the latter implies a neoclassical, monetary framing.

The results from the subsequent path analysis partially support the causeeffect relationship. No significant effect of customer fairness on performance was revealed, either directly or indirectly via the use of control systems. However, there is a significant positive indirect relationship between customer trust building and branch performance acting through the use of control systems. One plausible explanation could be the possibility of lack of consistency between what customers perceive as giving them satisfaction and what managers are focusing instead. For example, from customers' perspective pricing could be important that effect their satisfaction and/or retention whereas managers could see this issue differently. Some managers may realize this fact but that does not necessarily translate into response due to certain constraint (unique to the branch or bank wide). The indirect effect shows that control systems can be used to enhance the impact of customer trust building on branch performance. There are some implications for practitioner worthy to be discussed. First, Islamic banks may need to consider customer relation staff at branches as this has becoming industrial norms especially in conventional segment. Second, employee training is of importance to equip branch employees with skills and knowledge to meet customers' expectations. Islamic bank may differentiate themselves by focusing more on interactions (relational fairness and benevolence).

Given the impressive growth in the size and popularity of Islamic banking around the world, it is an increasingly pertinent domain for academic research. This study has sought to contribute to this literature from the perspective of organizational dynamics and organizational performance as perceived by branch managers. However, in common with applied research more generally, this study is not without its limitations. Exploring and mitigating these limitations could be fruitful terrain for future research. First, although the sample size of this study is reasonable it was still not sufficient to develop a full structural model. Further, and relatedly, because of the cross-sectional research design it is not possible to make inter-temporal inferences. Finally, branch managers' perceptions of fairness building, trust building, and performance are 
arguably problematic from the perspective of accurately gauging these phenomena. On the one hand, it would have been interesting to elicit views from a wider range of bank personnel (i.e., regular employees as well as branch managers). Whilst on the other hand it may have been beneficial to utilize more objective measurements, particularly with respect to performance. However, the literature is equivocal on the extent to which objective measurements are superior to subjective measurements of different phenomena, including performance (e.g., Bommer et al., 1995; Muckler \& Seven, 1992) and as such alternative operationalizations compared to those used in this study will not necessarily be preferable.

\section{References}

Abernethy, M., \& Vagnoni, E. (2004). Power, organizational design and behaviour. Accounting, Organizations and Society, 29, 207-225. https:/ / doi.org/10.1016/S0361-3682(03)00049-7

Abu-Tapanjeh, A. M. (2009). Corporate governance from the Islamic perspective: A comparative analysis with OECD principles. Critical Perspectives on Accounting, 20, 556567. https://doi.org/10.1016/j.cpa.2007.12.004

Adams, J. S. (1965). Inequity in social exchange. In L. Berkowitz (Ed.), Advances in experimental social psychology (Vol. 2, pp. 267-299). New York: Academic Press.

Ahrens, T., \& Chapman, C. S. (2004). Accounting for flexibility and efficiency: a field study of management control systems in a restaurant chain. Contemporary Accounting Research, 21(2), 271-301. https:// doi.org/10.1506/VJR6-RP75-7GUX-XH0X

Ambrose, M. L., \& Cropanzano, R. (2003). A longitudinal analysis of organizational fairness: An examination of reactions to tenure and promotion decisions. Journal of Applied Psychology, 88, 266-275. https:// doi.org/10.1037/0021-9010.88.2.266

Anthony, R. N., \& Govndarajan, V. (2007). Management Control Systems (12 ed.). Singapore: McGraw-Hill.

Ariff, M. (2017). Islamic banking in Malaysia: The changing landscape. Institutions and Economies, 9(2), 1-13.

Barney, J. B., \& Hansen, M. H. (1994). Trustworthiness as a source of competitive advantage. Strategic Management Journal, 15, 175-190. http:/ / dx.doi.org/10.1002/smj.4250150912

Bies, R. J., \& Moag, J. S. (1986). Interactional justice: communication criteria of fairness. In R. J. Lewicki, B. H. Sheppard \& M. H. Bazerman (Eds.), Research in negotiation in organizations (pp. 43-55). Greenwich, CT: JAI Press.

Bisbe, J., \& Otley, D. (2004). The effects of interactive use of management control systems on product innovation. Accounting, Organizations and Society, 29, 709-737. https://doi.org/10.1016/j.aos.2003.10.010

Bitner, M. J., Booms, B. H., \& Tetreault, M. S. (1990). The service encounter: diagnosing favorable and unfavorable incidents. Journal of Marketing, 54(January), 71-84. https://doi.org/10.2307/1252174

Boles, J. S., Johnson, J. T., \& Barksdale, H. C. (2000). How salespeople build quality relationships: A replication and extension. Journal of Business Research, 48(1), 75-81. https://doi.org/10.1016/S0148-2963(98)00078-2

Bommer, W. H., Johnson, J. L., Rich, G. A., Podsakoff, P. M., \& MacKenzie, S. B. (1995). On the interchangeability of objective and subjective measures of employee performance: A metaanalysis. Personnel Psychology, 48(3), 587-605. https://doi.org/10.1111/j.1744$\underline{\text { 6570.1995.tb01772.x }}$ 
Chaganti, R., \& Sambharya, R. (1987). Strategic orientation and characteristics of upper management. Strategic Management Journal, 8, 393-401.

Cham, T. (2018). Determinants of Islamic banking growth: an empirical analysis. International Journal of Islamic and Middle Eastern Finance and Management, 11(1), 18-39. https://doi.org/10.1108/IMEFM-01-2017-0023

Chenhall, R. H., \& Langfield-Smith, K. (1998). The relationship between strategic priorities, management techniques and management accounting: An empirical investigation using a systems approach. Accounting, Organizations and Society, 23, 243-264. https://doi.org/10.1016/S0361-3682(97)00024-X

Cox III, E. P. (1980). The optimal number of response alternatives for a scale: A review. Journal of Marketing Research, 17(4), 407-422. https:/ / doi.org/10.1016/S0361-3682(97)00024-X

Croasmun, J. T., \& Ostrom, L. (2011). Using likert-type scales in the social sciences. Journal of Adult Education, 40(1), 19-22.

Cropanzano, R., \& Folger, R. (1991). Procedural justice and worker motivation. In R. M. Steers \& L. W. Porter (Eds.), Motivation and work behavior (Vol. 5, pp. 131-143). New York: McGraw-Hill.

Cropanzano, R., \& Greenberg, J. (1997). Progress in Organizational Justice: Tunnelling Through the Maze. In C. L. Cooper \& I. T. Robertson (Eds.), International Review of Industrial and Organizational Psychology (Vol. 12, pp. 317-372). Chichester: Wiley.

Crosby, L. A., Kenneth, R. E., \& Cowles, D. (1990). Relationship quality in services selling: An interpersonal influence perspective. Journal of Marketing, 54(3), 68-81. https:// doi.org/10.1177\%2F002224299005400306

Dayan, M., Hassan Al-Tamimi, H., \& Elhadji, A. L. (2008). Perceived justice and customer loyalty in the retail banking sector in the UAE. Journal of Financial Services Marketing, 12(4), 320-330. https:// doi.org/10.1057/palgrave.fsm.4760085

Farrell, M.J. (1957). The measurement of productive efficiency. Journal of the Royal Statistical Society, 120(3), 253-281. https://doi.org/10.2307/2343100

Folger, R., \& Cropanzano, R. (1998). Organizational Justice and Human Resource Management. In D. Whetter (Ed.), Foundations for Organizational Science. London: Sage Publications.

Folger, R. M., \& Konovsky, A. (1989). Effects of procedural and distributive justice on reactions to pay raise decisions. Academy of Management Journal, 32, 115-130. URL: http://www.jstor.org/stable/256422

Gambling, T., Jones, R., \& Karim, R. A. A. (1993). Credible organizations: Self-regulation v. external standard-setting in Islamic banks and British charities. Financial Accountability $\mathcal{E}$ Management, 9(3), 195-207. https://doi.org/10.1111/j.1468-0408.1993.tb00373.x

Georgakakis, D., Greve, P., \& Ruigrok, W. (2017). Top management team faultliness and firm performance: Examining the CEO-TMT interface. The Leadership Quarterly, 28(6), 741-758. https:// doi.org/10.1016/j.leaqua.2017.03.004

Gilliland, S. W. (1993). The perceived fairness of selection systems: An organizational justice perspective. Academy of Management Review, 18(4), 694-734. https://doi.org/10.2307/258595

Golden, B. R. (1992). The past is the past - or is it? The use of retrospective accounts as indicators of past strategy. Academy of Management Journal, 35, 848-860. https://doi.org/10.2307/256318

Goold, M., \& Quinn, J. J. (1993). Strategic control: Milestones for long term performance. London: Pitman Publishing.

Greenberg, J. (1986). Determinants of perceived fairness of performance evaluations. Journal of Applied Psychology, 71, 340-342. 
Govindarajan, V., \& Shank, J. K. (1995). Strategic cost management: tailoring controls to strategies. In J. M. Reeve (Ed.), Readings and issues in cost management (pp. 73-90). New York: Warren, Gorham and Lamont.

Gupta, A. K., \& Govindarajan, V. (1984). Business unit strategy, managerial characteristics and business unit effectiveness at strategy implementation. Academy of Management Journal, 27, 24-41. https://doi.org/10.2307/255955

Hassan, A., Chachi, A. K., \& Abdul Latiff, S. (2008). Islamic marketing ethics and its impact on customer satisfaction in the Islamic banking industry. JKAU: Islamic Economics, 21(1), 2746.

Hollensbe, E. C., Khazanchi, S., \& Masterson, S. S. (2008). How do I assess if my supervisor and organization are fair? Identifying the rules underlying entity-based justice perceptions. Academy of Management Journal, 51, 1099-1116.

Hoque, Z. (2004). A contingency model of association between strategy, environmental uncertainty and performance measurement: impact on organizational performance. International Business Review, 13, 485-502. https://doi.org/10.1016/j.ibusrev.2004.04.003

Ittner, C. D., \& Larcker, D. F. (1997). Quality strategy, strategic control systems, and organizational performance. Accounting, Organizations and Society, 22(3/4), 293-314. https:// doi.org/10.1016/S0361-3682(96)00035-9

Jamal, A., \& Kamal, N. (2003). Factors influencing customer satisfaction in the retail banking sector in Pakistan. International Journal of Consumer Marketing, 13(2), 20-52. https:// doi.org/10.1108/eb047465

Kamaruddin, B. H., Safab, M. S., \& Mohd, R. (2008). Assessing production efficiency of Islamic banks and conventional bank Islamic windows in Malaysia. International Journal of Business and Management Science, 1(1), 31-48.

Kim, J.-O., \& Mueller, C. W. (1978). Factor analysis: Statistical methods and practical issues. Beverley Hills, CA: Sage Publications.

Leibenstein, H. (1966). Allocative efficiency versus X-efficiency. American Economic Review, 56(3), 392-415.

Lind, E. A., \& Tyler, T. R. (1988). The social psychology of procedural justice. New York: Plenum.

Luhmann, N. (1979). Trust and power. Wiley.

Masterson, S. S. (2001). A trickle-down model of organizational justice: relating employees' and customers' perceptions of and reactions to fairness. Journal of Applied Psychology, 86(4), 594. https:// doi.org/10.1037/0021-9010.86.4.594

Mattsson, J. (1994). Improving service quality in person-to-person encounters: integrating findings from a multi-disciplinary review. The Service Industries Journal, 14(1), 45-61. https://doi.org/10.1080/02642069400000004

Mayer, R. C., Davis, J. H., \& Schoorman, F. D. (1995). An integrative model of organizational trust. Academy of Management Journal, 20(3), https://doi.org/10.5465/amr.1995.9508080335

Metawa, S. A., \& Al-Mossawi, M. (1998). Banking behaviour of Islamic bank customers: Perspectives and implications. International Journal of Banking, 16(7), 299- 313. https:// doi.org/10.1108/02652329810246028

Naser, K., Jamal, A., \& Al-Khatib, K. (1999). Islamic banking: A study of customer satisfaction and preferences in Jordan. International Journal of Bank Management, 17(3), 135-150. https:// doi.org/10.1108/02652329910269275

Olson, D., \& Zoubi, T. A. (2008). Using accounting ratios to distinguish between Islamic and conventional banks in the GCC region. The International Journal of Accounting, 43(1), 45-65. https://doi.org/10.1016/j.intacc.2008.01.003 
Parnell, J. A. (1997). New evidence in the generic strategy and business performance debate: A research note. British Journal of Management, 8, 175-181. https://doi.org/10.1111/14678551.0049

Preston, C. C., \& Colman, A. M. (2000). Optimal number of response categories in rating scales: reliability, validity, discriminating power, and respondent preferences. Acta Psychologica, 104(1), 1-15. https://doi.org/10.1016/S0001-6918(99)00050-5

Rosly, S. A., \& Sanusi, M. M. (1999). The application of bai-al-inah and bai-al-dayn in Malaysian Islamic bonds: An Islamic analysis. International Journal of Islamic Financial Services, 1(2), 3-11.

Saeed, M., Ahmad, Z. U., \& Mukhtar, S. M. (2001). International marketing ethics from an Islamic perspective: A value maximization approach. Journal of Business Ethics, 32, 127-142. https://doi.org/10.1023/A:1010718817155

Schminke, M., Arnaud, A., \& Taylor, R. (2015). Ethics, values, and organizational justice: Individuals, organizations, and beyond. Journal of Business Ethics, 130(3), 727-736. https://doi.org/10.1007/s10551-014-2251-3

Simons, R. (1995). Levers of control. Cambridge, MA: Harvard Business School Press.

Sitkin, S. B. (1995). On the positive effect of legalization on trust. Research on Negotiation in Organization, 5, 185-217.

Tyler, T. R., \& Bies, R. J. (1990). Beyond formal procedures: The interpersonal context of procedural justice. In J. S. Carroll (Ed.), Applied social psychology and organizational settings (pp. 77-98). Hillsdale, NJ: Lawrence Eribaum Associates.

Tyler, T. R., \& Lind, E. A. (1992). A relational model of authority in groups. In M. Zanna (Ed.), Advances in experimental social psychology. In (Vol. 25, pp. 115-191). New York: Academic Press.

Urban, G. L., Sultan, F., \& Qualls, W. J. (2000). Placing trust at the center of your internet strategy. Sloan Management Review, 42, 39-49.

Velez, M. L., Sanchez, J. M., \& Alvarez-Dardet, C. (2008). Management control systems as inter-organizational trust builders in evolving relationships: Evidence from a longitudinal case study. Accounting, Organizations and Society, 33(7-8), 968-994. https://doi.org/10.1016/j.aos.2008.02.006

Zeithaml, V. A., Berry, L. L., \& Parasuraman, A. (1988). Communication and control processes in the delivery of service quality. Journal of Marketing, 52(2), 35-48. https://doi.org/10.2307/1251263 